\title{
Pengaruh Model Pembelajaran Koperatif dan Kemampuan Awal terhadap Hasil Belajar Peserta Didik (Studi pada Materi Pokok Hidrólisis Garam di Kelas Xi Ipa SMA Negeri 1 Mare)
}

\author{
The Influence of Cooperative Learning Models and Basic Skill toward \\ Students Learning Outcome (Study on the Subject Hydrolysis of Salt in Class \\ XI Science of SMA Negeri 1 Mare) \\ Evi Aspirani \\ SMAN 1 Mare, jalan Makmur no.1 Kec. Mare, Kabupaten Bone \\ Email: eviaspirani@yahoo.com
}

\begin{abstract}
ABSTRAK
Jenis penelitian adalah eksperimen semu menggunakan desain faktorial 2x3. Populasi dalam penelitian ini adalah peserta didik kelas XI IPA SMA Negeri 1 Mare. Sampel dipilih secara acak dan diambil dua kelas dari lima kelas. Pengujian hipotesis dilakukan menggunakan analisis varian dua arah GLM Univariat. Hasil penelitian ini menunjukkan bahwa (1) tidak terdapat perbedaan hasil belajar kimia peserta didik yang diajar dengan model pembelajaran koperatif tipe TPS dengan tipe GI pada materi pokok hidrólisis garam di kelas XI IPA SMA Negeri 1 Mare (2) terdapat perbedaan hasil belajar antara peserta didik yang mempunyai kemampuan awal yang tinggi, sedang, dan rendah. Kemampuan awal yang tinggi memberikan pengaruh yang lebih besar terhadap hasil belajar peserta didik pada materi hidrolisis garam dibandingkan kemampuan awal yang sedang dan rendah (3) tidak ada interaksi antara model pembelajaran dengan kemampuan awal dalam mempengaruhi hasil belajar peserta didik. Kata kunci: Model pembelajaran kooperatif, Kemampuan awal
\end{abstract}

\begin{abstract}
The type of research is quasi eksperiment with factorial design of $2 \times 3$. Population of this research was XI grade students of SMA Negeri 1 Mare. Sample was taken randomly 2 of five classes. The hypothesis test was done by two way analysis of variance GLM Univariate. The result shoms that (1) there is no differences of chemistry learning outcomes between students who were taught by using cooperative learning type TPS and by using cooperative learning type GI on the subject matter hydrolysis of salt in ClassXI Science of SMA Negeri 1 Mare; (2) there is differences of learning outcomes between students with high, fair, and low ability. Student with high skill give a big influence of their learning outcomes than students with fair and low skill; (3) there is no interaction between learning model with the basic skill of student toward their learning outcomes.
\end{abstract}

Keywords: Cooperative learning models, Basic skill 


\section{PENDAHULUAN}

Dominasi guru dalam pembelajaran menciptakan suasana pasif bagi peserta didik sehingga cenderung menunggu sajian guru daripada menghubungkan sendiri pengetahuan yang dimiliki untuk menghasilkan pengetahuan baru. Peserta didik hanya memperhatikan penjelasan guru, dan menyelesaikan soal-soal yang diberikan. Kondisi pembelajaran tersebut akhirnya akan mengurangi keterlibatan, interaksi dan konstruksi pengetahuan peserta didik. Dengan demikian tidak terjadi pemahaman yang mendalam pada aspek kognitif peserta didik dan belajar tidak pada kondisi belajar bermakna.

Kimia sebagai salah satu mata pelajaran yang diajarkan di SMA/MA, sebagai salah satu ilmu pengetahuan alam dimana peserta didik masih memiliki tingkat penguasaan yang rendah, khususnya di SMA negeri 1 Mare. Berdasarkan hasil pengamatan yang telah dilakukan melalui observasi kelas terhadap peserta didik, dan diskusi dengan guru mata pelajaran kimia menunjukan bahwa pencapaian kompetensi mata pelajaran kimia peserta didik masih kurang. Hal ini ditandai dengan skor hasil ulangan harian rata-rata masih berada pada persentase ketuntasan yang rendah yaitu $42 \%$ dan kurangnya minat dan motivasi peserta didik dalam mengikuti pelajaran. Asumsi dasar yang menyebabkan pencapaian kompetensi mata pelajaran kimia peserta didik kurang optimal disebabkan oleh pembelajaran yang masih terpusat pada guru dan belum adanya perhatian terhadap tingkat kemampuan awal peserta didik. Pembelajaran yang terpusat pada guru akan menciptakan suasana belajar yang kurang melibatkan peserta didik untuk ikut aktif dalam proses pembelajaran. Kondisi ini menyebabkan pembelajaran tidak pada kondisi belajar bermakna.

Salah satu model pembelajaran yang dapat digunakan adalah model pembelajaran koperatif tipe TPS dan GI dimana kedua model memiliki kelebihan yang dapat melibatkan siswa secara aktif dalam proses pembelajaran. Peserta didik tidak lagi pasif menunggu untuk menyerap pengetahuan yang diberikan oleh tenaga pendidik, tetapi dapat berdiskusi dalam kelompok masingmasing sehingga akan berada pada suasana pembelajaran dalam kerja kelompok yang lebih mengaktifkan peserta didik (Isjoni, 2007).

Setiap individu memiliki kemampuan belajar yang berbedabeda. Kemampuan awal merupakan kemampuan yang telah dimiliki oleh peserta didik sebelum mengikuti pelajaran yang akan diberikan. Kemampuan awal ini menggambarkan kesiapan peserta didik dalam menerima pelajaran yang akan disampaikan oleh guru. Kemampuan awal peserta didik sangat penting diketahui untuk melihat apakah peserta didik telah mempunyai pengetahuan yang merupakan prasyarat untuk mengikuti pelajaran dan sejauh mana peserta didik mengetahui materi apa yang akan disajikan. Hal ini 
Pengaruh Model Pembelajaran Koperatif dan Kemampuan Awal terhadap Hasil Belajar Peserta Didik (Studi pada Materi Pokok Hidrólisis Garam di Kelas XI IPA SMA Negeri I Mare)

merupakan pijakan dalam pemilihan strategi dan model pembelajaran yang lebih optimal. Ini dilakukan karena kemampuan awal amat penting peranannya dalam meningkatkan kebermaknaan pengajaran, yang selanjutnya membawa dampak dalam memudahkan proses internal yang berlangsung dalam diri peserta didik ketika belajar (Uno, H.B, 2010).

Peserta didik di SMA Negeri 1 Mare berasal dari berbagai latar belakang menyebabkan minat, sikap, motivasi belajar juga berbeda-beda. Tingkat kemampuan awal yang dimiliki memiliki tingkatan yang berbeda pula dimulai dari tingkat kemampuan awal tinggi, sedang, dan rendah.

Salah satu pokok bahasan pada kelas XI kurikulum SMA adalah Hidrolisis garam. Pemahaman pada konsep hidrolisis garam ditunjang oleh pemahaman pada pokok bahasan lain seperti asam basa dan larutan penyangga. Materi hidrolisis garam yang biasanya dipaparkan secara meruah dapat diinovasi dengan menggunakan model pembelajaran kooperatif tipe TPS dan GI agar peserta didik dapat lebih aktif mencari informasi yang lebih luas mengenai materi hidrolisis garam. Penggunaan model TPS dan GI diharapkan akan membantu peserta didik untuk memahami konsep-konsep yang ada didalamnya, sehingga penelitian ini bertujuan untuk mengetahui pengaruh model pembelajaran kooperatif dan kemampuan awal terhadap hasil belajar peserta didik.

\section{METODE PENELITIAN}

Jenis penelitian ini adalah quasi eksperimen (eksperimen semu) yang bertujuan untuk mengetahui perbedaan pengaruh model pembelajaran kooperatif dan kemampuan awal terhadap hasil belajar kimia peserta didik, interaksi model pembelajaran dengan kemampuan awal peserta didik yang pada proses pembelajarannya menggunakan model pembelajaran kooperatif tipe Think Pair Share (TPS) dan model pembelajaran koperatif tipe Group Investigation (GI) untuk masing-masing kelas eksperimen.

Penelitian ini dilaksanakan di SMA Negeri 1 Mare Kabupaten Bone. Populasi dalam penelitian ini adalah seluruh peserta didik kelas XI IPA SMA Negeri 1 Mare yang terdiri dari lima kelas. Jumlah peserta didik keseluruhan adalah 198 orang yang terdiri dari peserta didik perempuan sebanyak 136 orang dan peserta didik laki-laki 62 orang.

Pemilihan sampel dalam penelitian ini dilakukan secara acak kelas (cluster random sampling) dan di dapatkan dua kelas dari lima kelas yang mempunyai karakteristik yang sama (bersifat homogen) karena masing-masing kelas memiliki kemampuan yang merata. Kedua kelas yang terpilih sebagai kelas eksperimen kemudian diacak lagi untuk menentukan pembagian kelasnya. Kelas XI IPA 2 (kelas eksperimen) diajar dengan menggunakan model pembelajaran kooperatif tipe TPS dan kelas XI IPA 1 (kelas eksperimen) diajar dengan menggunakan model pembelajaran koperatif tipe GI. 
Desain yang digunakan dalam penelitian ini adalah desain faktorial 2 x 3 (Tabel 1). Desain faktorial digunakan untuk menyelidiki apakah pengaruh variabel bebas dapat digeneralisasikan melalui semua tingkat pada variabel atribut atau apakah tidak ada pengaruh khusus dari tingkatan pada variabel atribut. Disebut desain faktorial karena hampir semua faktor dikombinasikan atau disilangkan dengan hampir semua taraf tiap faktor lainnya yang ada dalam eksperimen.

Desain faktorial yang digunakan dikatagorikan sebagai desain faktorial $2 \times 3$ karena desain faktorial ini menggunakan variabel bebas model pembelajaran yang dibagi dua yaitu model pembelajaran koperatif tipe TPS dan GI dan variabel atribut dibagi menjadi tiga kelompok kemampuan awal yaitu tinggi, sedang, dan rendah.

Tabel 1. Desain Faktorial 2 x 3

\begin{tabular}{|c|c|c|c|}
\hline $\begin{array}{l}\text { Model } \\
\text { Pembelajaran }\end{array}$ & $\begin{array}{l}\text { Kemampuan } \\
\text { awal tinggi } \\
\left(\mathrm{B}_{1}\right)\end{array}$ & $\begin{array}{l}\text { Kemampuan } \\
\text { awal sedang } \\
\qquad\left(\mathbf{B}_{2}\right)\end{array}$ & $\begin{array}{c}\text { Kemampuan } \\
\text { awal rendah } \\
\left(\mathbf{B}_{3}\right) \\
\end{array}$ \\
\hline $\begin{array}{l}\text { Model pembelajaran } \\
\text { kooperatif tipe TPS }\left(\mathrm{A}_{1}\right)\end{array}$ & $\mathrm{A}_{1} \mathrm{~B}_{1}$ & $\mathrm{~A}_{1} \mathrm{~B}_{2}$ & $\mathrm{~A}_{1} \mathrm{~B}_{3}$ \\
\hline $\begin{array}{l}\text { Model Pembelajaran } \\
\text { koperatif tipe GI }\left(\mathrm{A}_{2}\right)\end{array}$ & $\mathrm{A}_{2} \mathrm{~B}_{1}$ & $\mathrm{~A}_{2} \mathrm{~B}_{2}$ & $\mathrm{~A}_{2} \mathrm{~B}_{3}$ \\
\hline
\end{tabular}

Variabel pada penelitian terdiri dari variabel bebas, variabel atribut, dan variabel terikat, yaitu:

\section{A. Variabel bebas}

Model pembelajaran (A) merupakan variabel bebas yang terdiri atas dua bagian yaitu: model pembelajaran koperatif tipe TPS $\left(\mathrm{A}_{1}\right)$ dan model pembelajaran koperatif tipe GI $\left(\mathrm{A}_{2}\right)$.

\section{B. Variabel atribut}

Kemampuan awal (B) merupakan variabel atribut yang terdiri atas tiga bagian yaitu: kemampuan awal tinggi $\left(\mathrm{B}_{1}\right)$, kemampuan awal sedang $\left(\mathrm{B}_{2}\right)$, dan kemampuan awal rendah $\left(\mathrm{B}_{3}\right)$. Pengelompokan yang dilakukan didasarkan pada data hasil belajar peserta didik yang diperoleh dari materi sebelumnya.

\section{Variabel terikat}

Varibel terikat adalah hasil belajar kognitif mata pelajaran kimia peserta didik khususnya pada materi pokok hidrolisis garam.

Instrumen yang digunakan dalam penelitian ini adalah tes hasil belajar dan lembar observasi. Pengumpulan data dalam penelitian ini dilakukan dengan pemberian post-test berjumlah 8 nomor soal essay. 
Data yang diperoleh selama penelitian ini dianalisis statistik secara deskriptif dan inferensial. Análisis statistik inferensial adalah análisis statistik yang digunakan untuk menguji hipotesis dengan menggunakan analisis varian dua arah GLM Univariat. Sebelum dilakukan análisis varian dua arah, maka terlebih dahulu dilakukan uji prasyarat berupa uji normalitas dan homogenitas.

\section{HASIL DAN PEMBAHASAN}

\section{A. Hasil}

Analisis deskriptif hasil belajar peserta didik pada materi pokok hidrolisis garam yang diajar dengan menggunakan model pembelajaran koperatif tipe TPS dan model pembelajaran koperatif tipe GI dengan pengelompokan kemampuan awal tinggi, sedang, dan rendah berdasarkan data hasil posttest dapat dilihat pada Tabel 2.

Tabel 2. Statistik Deskriptif Hasil Belajar Kimia Peserta Didik yang Diajar dengan Model Pembelajaran Koperatif Tipe TPS dan GI

\begin{tabular}{lcc}
\hline \multicolumn{1}{c}{ Statistik } & Posttest tipe TPS & Posttest tipe GI \\
\hline N & 39 & 39 \\
Skor maks & 100 & 100 \\
Rata-rata & 75,37 & 76,59 \\
Median & 75 & 75 \\
Skor tertinggi & 93 & 99 \\
Skor terendah & 61 & 63 \\
Standar deviasi & 10,284 & 10,713 \\
Jangkauan & 32 & 36 \\
\hline
\end{tabular}

$\begin{array}{lcl}\text { Terlihat bahwa data hasil } & \text { nominal lebih tinggi dibandingkan } \\ \text { belajar peserta didik yang diajar } & \text { dengan peserta didik yang diajar } \\ \text { dengan menggunakan } \text { model } & \text { dengan model pembelajaran koperatif } \\ \text { pembelajaran koperatif tipe GI secara } & \text { tipe TPS. }\end{array}$

Tabel 3. Statistik Deskriptif Hasil Belajar Kimia Peserta Didik Berdasarkan Kemampuan Awal

\begin{tabular}{lccc}
\hline \multicolumn{1}{c}{ Statistik } & $\begin{array}{c}\text { Kemampuan Awal } \\
\text { Tinggi }\end{array}$ & $\begin{array}{c}\text { Kemampuan Awal } \\
\text { Sedang }\end{array}$ & $\begin{array}{c}\text { Kemampuan Awal } \\
\text { Rendah }\end{array}$ \\
\hline N & 14 & 52 & 12 \\
Skor maksimal & 100 & 100 & 100 \\
Rata-rata & 86,77 & 74,08 & 70,08 \\
Median & 86,77 & 72 & 66 \\
Skor tertinggi & 99 & 95 & 89 \\
Skor terendah & 78 & 61 & 62 \\
Standar deviasi & 7,272 & 9,344 & 9,308 \\
Jangkauan & 21 & 34 & 27 \\
\hline
\end{tabular}


Tabel 3 memperlihatkan deskripsi hasil belajar peserta didik berdasarkan tingkat kemampuan awal secara keseluruhan pada kedua model pembelajaran koperatif. Terlihat bahwa jumlah peserta didik yang berada pada kemampuan awal tinggi sebanyak 14 orang, kemampuan awal sedang sebanyak 52 orang, dan kemampuan awal rendah sebanyak 12 orang.
Peserta didik yang memiliki kemampuan awal sedang jumlahnya banyak untuk kedua kelas eksperimen, sedangkan jumlah peserta didik yang memiliki kemampuan awal tinggi dan rendah masih kurang. Hal inilah yang menjadi penyebab nilai rata-rata kelas untuk tiap kelas control dan kelas eksperimen masih dalam skala sedang.

Tabel 4. Deskripsi Skor Rata-Rata Hasil Belajar Peserta Didik Ditinjau dari Model Pembelajaran dan Kemampuan Awal

\begin{tabular}{|c|c|c|c|c|}
\hline Model $\begin{array}{l}\text { Kemampuan } \\
\text { Pembelajaran }\end{array}$ & $\begin{array}{c}\text { Kemampuan } \\
\text { awal tinggi } \\
\left(\mathrm{B}_{1}\right) \\
\end{array}$ & $\begin{array}{c}\text { Kemampun } \\
\text { awal sedang } \\
\left(\mathbf{B}_{2}\right)\end{array}$ & $\begin{array}{c}\text { Kemampuan } \\
\text { awal rendah } \\
\left(\mathbf{B}_{3}\right) \\
\end{array}$ & \\
\hline $\begin{array}{l}\text { Model Pembelajaran } \\
\text { Kooperatif tipe TPS } \\
\left(\mathrm{A}_{1}\right)\end{array}$ & $\begin{array}{l}86,17 \\
6,676 \\
6\end{array}$ & $\begin{array}{l}73,59 \\
9,744 \\
27\end{array}$ & $\begin{array}{l}72,33 \\
9,873 \\
6\end{array}$ & $\begin{array}{l}\bar{X}=77,36 \\
\mathrm{~S}=10,284 \\
\mathrm{n}=39\end{array}$ \\
\hline $\begin{array}{l}\text { Model Pembelajaran } \\
\text { koperatif tipe GI } \\
\qquad\left(\mathrm{A}_{2}\right)\end{array}$ & $\begin{array}{l}87,38 \\
8,816 \\
8\end{array}$ & $\begin{array}{l}74,56 \\
9,065 \\
25\end{array}$ & $\begin{array}{l}67,83 \\
10,028 \\
6\end{array}$ & $\begin{array}{l}\bar{X}=76,59 \\
\mathrm{~S}=10,713 \\
\mathrm{n}=39\end{array}$ \\
\hline $\begin{array}{l}\bar{X} \\
\mathrm{~S} \\
\mathrm{~N}\end{array}$ & $\begin{array}{l}86,77 \\
7,272 \\
14\end{array}$ & $\begin{array}{l}74,08 \\
9,344 \\
52\end{array}$ & $\begin{array}{l}70,08 \\
9,344 \\
12\end{array}$ & \\
\hline
\end{tabular}

Rata-rata hasil belajar peserta didik yang diajar dengan model pembelajaran kooperatif tipe TPS dan peserta didik yang diajar dengan model pembelajaran koperatif tipe GI masing-masing 77,36 dan 76,59. Ratarata hasil belajar dengan kemampuan awal tinggi, kemampuan awal sedang, dan kemampuan awal rendah masing- masing 86.77, 74.08, 70.08. Untuk membuktikan pengaruh model pembelajaran dan kemampuan awal terhadap hasil belajar dan signifikansi perbedaan rata-rata hasil belajar kemampuan awal tinggi, sedang, dan rendah, data dianalisis dengan menggunakan análisis varian dua arah GLM Univariat. 
Tabel 5.Hasil Analisis Varian Dua Arah GLM Univariat

\begin{tabular}{lll}
\multicolumn{1}{c}{ Sumber } & F & Sig \\
\hline Model & .089 & .766 \\
Kemampuan awal & 2,758 & .000 \\
Model *Kemampuan awal & .449 & .640 \\
\hline
\end{tabular}

Dari tabel 5 hasil analisis varian dua arah GLM Univariat dapat diinterpretasikan sebagai berikut:

\section{Hipotesis 1}

Ada perbedaan hasil belajar kimia antara peserta didik yang diajar dengan model pembelajaran koperatif tipe TPS dengan yang diajar dengan menggunakan model pembelajaran koperatif tipe GI pada materi pokok hidrolisis garam di kelas XI IPA SMA Negeri 1 Mare. disusun hipótesis statistik yaitu:

$$
\begin{aligned}
& \mathrm{H}_{0}: \mu \mathrm{A}_{1}=\mu \mathrm{A}_{2} \\
& \mathrm{H}_{1}: \mu \mathrm{A}_{1} \neq \mu \mathrm{A}_{2}
\end{aligned}
$$

Kriteria pengujian: terima $\mathrm{H}_{0}$ jika nilai signifikansi $>\alpha=0,05$. Dari hasil pengujian diperoleh signifikansi 0,766> $\alpha=0,05$ sehingga $\mathrm{H}_{0}$ gagal ditolak. Hal ini berarti tidak ada perbedaan hasil belajar kimia antara peserta didik yang diajar dengan model pembelajaran koperatif tipe TPS dengan yang diajar dengan model pembelajaran koperatif tipe GI pada materi pokok hidrólisis garam di kelas XI IPA SMA Negeri 1 Mare. Hal ini dapat dilihat bahwa tidak ada pengaruh model pembelajaran koperatif terhadap hasil belajar peserta didik pada materi pokok hidrólisis garam di kelas XI IPA SMA Negeri 1 Mare.

\section{Hipotesis 2}

"Ada perbedaan hasil belajar kimia antara peserta didik yang memiliki kemampuan awal tinggi, sedang, dan rendah pada materi pokok hidrolisis garam di kelas XI IPA SMA Negeri 1 Mare" disusun hipótesis statistik yaitu:

$$
\begin{aligned}
& H_{0}: \mu B_{1}=\mu B_{2}=\mu B_{3} \\
& H_{1}: \mu B_{1} \neq \mu B_{2} \neq \mu B_{3}
\end{aligned}
$$

Kriteria pengujian: terima $\mathrm{H}_{0}$ jika nilai signifikansi $>\alpha=0,05$. Dari hasil pengujian diperoleh signifikansi $0,000<\alpha=0,05$ sehingga $\mathrm{H}_{0}$ ditolak atau $\mathrm{H}_{1}$ diterima. Hal ini berarti ada perbedaan hasil belajar kimia antara peserta didik yang memiliki kemampuan awal tinggi, sedang, dan rendah pada materi pokok hidrólisis garam di kelas XI IPA SMA Negeri 1 Mare. Hal ini dapat dilihat bahwa ada pengaruh kemampuan awal terhadap hasil belajar kimia peserta didik pada materi pokok hidrólisis garam di kelas XI IPA SMA Negeri 1 Mare.

\section{Hipotesis 3}

Terdapat interaksi antara model pembelajaran koperatif dengan kemampuan awal dalam mempengaruhi hasil belajar kimia peserta didik pada materi pokok hidrolisis garam di kelas XI IPA SMA Negeri 1 Mare" disusun hipotesis statistik yaitu: 
$\mathrm{H}_{0}: \mu\left(\mathrm{A}_{1} \mathrm{~B}_{1}-\mathrm{A}_{2} \mathrm{~B}_{1}\right)=\mu\left(\mathrm{A}_{1} \mathrm{~B}_{2}-\right.$ $\left.A_{2} B_{2}\right)=\mu\left(A_{1} B_{3}-A_{2} B_{3}\right)$

$\mathrm{H}_{1}$ : paling sedikit ada satu selisih rata-rata kelompok yang berbeda.

Kriteria pengujian: terima $\mathrm{H}_{0}$ jika nilai signifikansi $>\alpha=0,05$. Dari hasil pengujian diperoleh signifikansi $0,640>\alpha=0,05$ sehingga Ho diterima tidak ada interaksi antara model pembelajaran koperatif dengan kemampuan awal dalam mempengaruhi hasil belajar kimia peserta didik pada materi pokok hidrolisis garam di kelas XI IPA SMA Negeri 1 Mare. Penolakan terhadap hipotesis yang didasarkan pada angka signifikansi yang lebih besar dari $\alpha$ juga dapat dipertegas dengan kesejajaran garis pada gambar grafik rata-rata hasil belajar dengan kemampuan awal peserta didik.

\section{B. Pembahasan}

\section{Pengaruh model pembelajaran koperatif terhadap hasil belajar}

Hipotesis satu yaitu ada perbedaan hasil belajar kimia antara peserta didik yang diajar dengan model pembelajaran koperatif tipe TPS dengan yang diajar dengan menggunakan model pembelajaran koperatif tipe GI pada materi pokok hidrolisis garam di kelas XI IPA SMA Negeri 1 Mare. Hasil analisis inferensial diperoleh signifikansi 0,766> $\alpha=0,05$ sehingga $H_{0}$ gagal ditolak. Sehingga tidak ada perbedaan hasil belajar kimia antara peserta didik yang diajar dengan model pembelajaran koperatif tipe TPS dengan yang diajar dengan model pembelajaran koperatif tipe GI pada materi pokok hidrólisis garam di kelas XI IPA SMA Negeri 1 Mare.

Hasil analisis deskriptif memperlihatkan rata-rata hasil belajar kimia peserta didik setelah diajar dengan menggunakan model pembelajaran koperatif tipe TPS dan GI berturut-turut adalah 75.77 dan 76,59. Selisih yang diperoleh dari ratarata hasil belajar kimia peserta didik adalah 0,85. Jika ditinjau dari selisih antara rata-rata hasil belajar pada model pembelajaran koperatif tipe TPS dan GI yang sangat kecil maka dikatakan perbedaan pada hasil belajar kedua model tidak signifikan. Identifikasi adanya perbedaan terhadap rata-rata hasil belajar merupakan indikasi adanya pengaruh. Tidak terdapatnya perbedaan yang signifikan menyebabkan tidak ada pengaruh pada model pembelajaran koperatif tipe TPS dan GI terhadap hasil belajar peserta didik pada materi pokok hidrolisis garam.

\section{Pengaruh kemampuan awal terhadap hasil belajar}

Hipotesis dua yaitu ada perbedaan hasil belajar kimia antara peserta didik yang memiliki kemampuan awal tinggi, sedang, dan rendah pada materi pokok hidrolisis garam di kelas XI IPA SMA Negeri 1 Mare. Hasil analisis inferensial memperlihatkan bahwa signifikansi yang diperoleh $0,000<\alpha=0,05$. Hasil ini menyebabkan Ho ditolak dan $\mathrm{H}_{1}$ diterima yaitu ada perbedaan hasil belajar kimia antara peserta didik yang memiliki kemampuan awal tinggi, sedang, dan rendah pada materi pokok hidrolisis garam di kelas XI IPA SMA 
Pengaruh Model Pembelajaran Koperatif dan Kemampuan Awal terhadap Hasil Belajar Peserta Didik (Studi pada Materi Pokok Hidrólisis Garam di Kelas XI IPA SMA Negeri I Mare)

Negeri 1 Mare. Identifikasi adanya perbedaan hasil belajar kimia antara peserta didik yang memiliki kemampuan awal tinggi, sedang, dan rendah pada materi pokok hidrolisis garam merupakan indikasi adanya pengaruh kemampuan awal terhadap hasil belajar peserta didik.

Pada kemampuan awal sedang diperoleh hasil untuk model pembelajaran koperatif tipe TPS 73,59 dan tipe GI 74,56. Pada kemampuan awal rendah untuk model pembelajaran koperatif tipe TPS 72,33 dan pada GI 67,83. Rata-rata hasil belajar dengan kemampuan awal tinggi dan sedang untuk model pembelajaran koperatif tipe GI berada pada posisi yang lebih tinggi. Namun pada kemampuan awal rendah, model pembelajaran koperatif tipe TPS memiliki hasil rata-rata yang lebih tinggi dibandingkan dengan tipe GI. Dapat dikatakan bahwa untuk peserta didik yang memiliki kemampuan awal tinggi dan sedang dapat diberikan model pembelajaran koperatif tipe GI sedangkan peserta didik dengan kemampuan awal rendah dapat diberikan model pembelajaran koperatif tipe TPS.

\section{Interaksi antara model pembelajaran koperatif dengan kemampuan awal}

Hipotesis tiga yaitu terdapat interaksi antara model pembelajaran koperatif dengan kemampuan awal dalam mempengaruhi hasil belajar kimia peserta didik pada materi pokok hidrolisis garam di kelas XI IPA SMA Negeri 1 Mare. Hasil analisis inferensial memberikan signifikansi $0,640>\alpha=0,05$ sehingga Ho diterima yaitu tidak terdapat interaksi antara model pembelajaran koperatif dengan kemampuan awal dalam mempengaruhi hasil belajar kimia peserta didik pada materi pokok hidrolisis garam di kelas XI IPA SMA Negeri 1 Mare

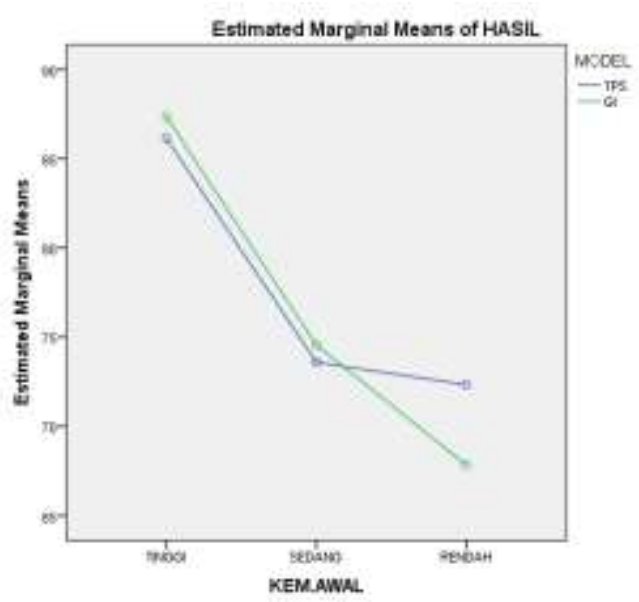

Gambar 1. Grafik interaksi antara kemampuan awal dan model pembelajaran.

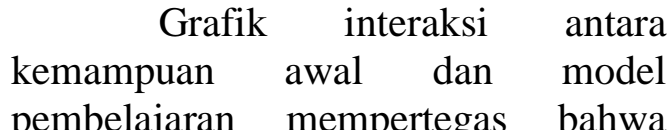
model pembelajaran koperatif yang digunakan tidak salingmemberikan pengaruh terhadap hasil belajar peserta didik pada materi pokok hidrolisis garam untuk siswa yang berkemampuan awal tinggi, sedang, dan rendah.

Penolakan terhadap hipotesis yang didasarkan pada angka signifikansi yang lebih besar dari $\alpha$ juga dapat dipertegas dengan kesejajaran garis pada gambar grafik rata-rata hasil belajar dengan kemampuan awal peserta didik. 
Pengaruh Model Pembelajaran Koperatif dan Kemampuan Awal terhadap Hasil Belajar Peserta Didik (Studi pada Materi Pokok Hidrólisis Garam di Kelas XI IPA SMA Negeri I Mare)

\section{KESIMPULAN DAN SARAN}

\section{A. Kesimpulan}

1. Tidak ada pengaruh model pembelajaran koperatif (tipe TPS dan GI) terhadap hasil belajar peserta didik pada materi pokok hidrólisis garam di kelas XI IPA SMA Negeri 1 Mare.

2. Ada pengaruh kemampuan awal terhadap hasil belajar kimia peserta didik pada materi pokok hidrólisis garam di kelas XI IPA SMA Negeri 1 Mare

3. Tidak ada interaksi antara model pembelajaran koperatif dengan kemampuan awal dalam mempengaruhi hasil belajar kimia peserta didik pada materi pokok hidrolisis garam di kelas XI IPA SMA Negeri 1 Mare.

\section{B. Saran}

Hal yang dapat disarankan adalah kepada guru untuk memperhatikan kemampuan awal yang dimiliki oleh peserta didik dalam proses pembelajaran. Pada pembelajaran dengan model kooperatif tipe GI harus betul-betul memperhatikan tingkat keragaman peserta didik agar hambatan dalam diskusi kelompok dapat diatasi utamanya dalam melakukan investigasi kelompok.

\section{DAFTAR PUSTAKA}

Isjoni. 2007. Cooperative Learning. Bandung: Alfabeta.

Uno, H.B. 2010. Orientasi Baru Dalam Psikologi Pembelajaran. Jakarta: PT. Bumi Aksara 